\title{
EXPRESAR UN POSICIONAMIENTO, EXPONER LA INTIMIDAD: LA IMAGEN DE AUTORA EN RITA INDIANA Y SU "YO" AUTORIAL"
}

\author{
por \\ Fernanda Bustamante Escalona \\ Universitat Autònoma de Barcelona
}

Estos autores tienen esta particularidad de que no son solamente autores de sus obras, de sus libros.

Han producido algo de más: la posibilidad y la regla de formación de otros textos.

Michel Foucault, ¿Qué es un autor?

No cabe duda de que revisar la trayectoria de Rita Indiana (Santo Domingo, 1977) -incesante, inquieta, diversa-, que comprende tanto a su labor escritural como a sus proyectos audiovisuales, musicales y performáticos, junto a los diferentes reconocimientos que ha recibido -tanto en éxito como en prestigio artístico-, no solo da cuenta de cómo su obra trasciende las fronteras de la media isla del Caribe, insertándose en un circuito cultural internacional; sino sobre todo de cómo convergen su propuesta estilística-artística-retórica y sus estrategias de escenificación y visibilización, componiendo una imagen autorial en la que en su corpus-obra y en su corpus-subjetividad se inscribe un posicionamiento estético-político que no le teme a irrumpir ni a incomodar.

La polifacética artista dominicano-caribeña Rita Indiana se ha consagrado como una de las principales voces del actual panorama literario y artístico latino ehispanoamericano. Si bien, a la fecha, su obra ha sido ampliamente abordada y problematizada por diferentes críticos e investigadores, desde los estudios literarios, culturales, etnomusicales, y atendiendo a los enfoques de género y poscoloniales, principalmente, en esta ocasión presentaré una aproximación a Rita Indiana desde los estudios autoriales recientes.

\footnotetext{
1 Este artículo se inscribe en los proyectos "Carto(corpo)grafias: narradoras hispanoamericanas del siglo XXI" (Fondecyt-Chile Regular 1180522) de la Comisión Nacional de Investigación Científica y Tecnológica (CONICYT) del Gobierno de Chile (Lorena Amaro IR) del que soy co-investigadora; y "Literatura hispanoamericana y literatura mundial: análisis de correspondencia múltiple de las redes transatlánticas actuales" (FFI2016-78058-P) del Ministerio de Economía y Competitividad del Gobierno de España (Dunia Gras IP), del que formo parte de su equipo de trabajo.
} 
Para ello, y teniendo en cuenta su obra literaria y performativa, realizaré un recorrido por su carrera artística y su proyección en el campo cultural (Bourdieu), centrándome tanto en diferentes elementos extraliterarios y contextuales de sus actos de enunciación, que han participado e intervenido en la construcción y escenificación de su imagen de autora -disidente, disruptiva, comprometida-así como en algunos de sus enunciadostextos-obras de corte sociopolítico y autorreferencial que reafirman esta imagen y postura de autora que ha configurado.

No voy a negar que la realización de este ejercicio crítico interpretativo me presenta ciertas disyuntivas, sobre todo porque trae consigo un encasillamiento o un etiquetamiento que -si bien hoy en día, en nuestras dinámicas del taggear, nos resulta algo tan cotidiano- también conduce a un endiosamiento o endemoniamiento de la figura autorial analizada, con lo que siempre está la duda de hasta qué punto se desea contribuir en ello o no. Pero de antemano debo asumir ese riesgo.

¿Cómo vemos, o hemos visto, a Rita Indiana? ¿Cómo nos la presentan? ¿Cómo se ha articulado su imagen de autora en este "retorno"? ¿Hasta qué punto la construcción de una imagen de autor y la defensa de una postura autorial te puede coartar o determinar tu producción futura o cómo contribuye a la inserción en el campo cultural? Son algunas de las preguntas que han guiado esta lectura.

Los estudios autoriales recientes -ya sea desde propuestas teóricas como la sociocrítica, la sociología de la literatura o el análisis del discurso francés- buscan la recuperación de la relación autor/obra comprendiendo a la figura autorial como un producto textual e histórico en el que participan tanto el autor y su obra como otros agentes de la cultura vinculados a la institucionalidad, el mercado, la recepción. Es decir, como un artificio cultural en el que intervienen dispositivos normativos no solo sociales y políticos, sino también propios del ámbito del arte y los medios, así como la propia contingencia y contextos de producción y recepción. En vista de ello, la figura autorial, lejos de ser estática y eterna, está sujeta a modificaciones y reformulaciones: "Devenir autor es un proceso que no tiene lugar en la habitación propia, aislada de la escritura, sino en la escena social y política, una escena en la cual la autorialidad depende de la mirada ajena y, por lo tanto, de la institución de una imagen reconocible y doblemente impropia: construida mediante relatos colectivos, y vulnerable a las múltiples reelaboraciones y reescrituras de los agentes del campo cultural" (Pérez, Torras y Cróquer 24).

A partir de esta idea, en este intento por observar la materialización de la figura autorial de Rita Indiana, me serviré de dos categorías estrechamente vinculadas. Por una parte, la noción de imagen de autor/a, de Dominique Maingueneau, vista como la representación o figuración de una autoría que surge como consecuencia de la confluencia de las propias palabras, gestos y obra de el/la autor/a con los diversos discursos y acciones de otros agentes del campo cultural, que, con sus respectivos intereses, contribuyen a modelarla, activarla, legitimarla: 
Lo quiera o no el escritor construye una imagen de sí a través de una multitud de comportamientos verbales o no verbales mediante los cuales muestra lo que es para él ser escritor. Pero su imagen de autor efectiva se elabora por una parte, en la interacción entre esos comportamientos y las obras; y, por otra parte, en la interacción entre esas obras y las reacciones [de los públicos, críticos, profesores...]. (Maingueneau 23)

Junto con esto, me valdré de la idea de postura, de Jérôme Meizoz, entendiéndola como el resultado de aquellas estrategias y artificios utilizados por el/la autor/a para posicionarse en el campo cultural de una determinada manera y por un tiempo concreto, que comprenden tanto la dimensión retórica (textual) como la comportamental (contextual): “La definición que propongo de la postura comprende tanto la presentación que el autor hace de sí mismo y las conductas públicas asumidas en la institución literaria (premios, discursos, banquetes, entrevistas públicas, etc.) como la imagen que proyecta en y a través del discurso" (“¿Qué entendemos?” 193).

De la mano de la forma de poner en escena a la autoría en un espacio social (y público), donde participan el propio discurso creado-enunciado-promovido por el/la autor/a, y los dispositivos utilizados tanto para la autofiguración como por los agentes externos, atenderé también al marco sociotópico en el que se inscribe la autoría (Diaz, "Las escenografías autoriales" 160). Con ello me refiero a los espacios concretos donde se hace la toma de palabra, a los lugares y contextos donde se pone en acto el discurso, la obra, la condición de autor/a. Al mismo tiempo que me sirvo de la categoría de “escenografía literaria o escenografía autorial” de José-Luis Diaz, entendida como la "puesta en escena del yo en un espacio público donde, en efecto, la literatura tiende a convertirse en sagrada pero donde tiende también [...] a escenificarse, en un 'campo literario’ que, a la vez que deviene sagrado, se convierte en más y más escénico” (157; cursiva del original).

En este sentido, y al ser el objeto de estudio una autora contemporánea, el presente análisis implica tomar en cuenta que su imagen y "yo" autorial se construyen en una época globalizada, con los medios de comunicación en explosión, y sujeta a la hipermedialidad y al auge de las redes sociales. Es decir, en la era de los perfiles, los hashtag, los "likes". Por lo que cabe observar también el complejo trabajo de mediatización y exhibición pública que realizan los autores "regidos por los formatos propios de la era del espectáculo" (Meizoz, "Escribir” 257).

REVISAR LA TRAYECTORIA DE LA(s) IMÁGEN(ES)-POSTURA(s) DE AUTORA EN Rita INDiANA

Si bien esta no es la ocasión para analizar la obra de Rita Indiana propiamente, cabe señalar que esta se ha destacado por sus experimentaciones estilísticas -libres de toda regulación y abiertas a relacionar referentes locales insulares con globales y mediáticos, así como de servirse de todo tipo de registros discursivos e idiomáticos-;

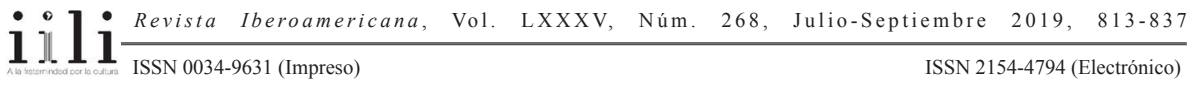


por poner en escena a corporalidades y subjetividades que suelen estar elididas en el inventario social hegemónico dominicano -como la comunidad afrodescendiente, particularmente la haitiana-; y por inscribir su trabajo en un discurso LGTBQ. Así, la crítica ha coincidido en valorar a su obra por su contradiscursividad, por su resistencia a las relaciones hegemónicas del poder, por su ruptura con la heteronormatividad, el patriarcado, el antihaitianismo y por su problematización de la frontera, en todas sus acepciones. ${ }^{2}$ De esta forma, a lo largo de su trayectoria autorial-que comienza en 1998 cuando publica su primer libro de cuentos, Rumiantes, y que se extiende a la actualidad-, su imagen/postura de autora se identifica con la subversión, la irrupción, la disidencia, la provocación, y una larga lista de sustantivos que remiten a una resistencia a la norma y a la oficialidad. Situación que en su momento fue vista como una actitud periférica y alternativa, como outsider, pero que hoy en día, cada vez más, lo podríamos vincular como más mainstream. ${ }^{3}$

En vista de ello, pensar en la autoría en Rita Indiana trae consigo pensar en la visibilidad en un doble sentido. La autora es visible en cuanto a su propia contextura física -blanca, de proporciones delgadas, sin curvas y de gran estatura (1,90 m)-, al mismo tiempo que, tanto en su condición de compositora y música como de escritora, es visible al ser una figura mediática que ha gozado de reconocimiento artístico, pero sobre todo de celebridad artística. ${ }^{4} \mathrm{Y}$ precisamente esta visibilidad dual nos permite establecer el vínculo entre su propuesta estética (narrativa y audiovisual) y sus imágenes de autora. Para ello, y como primera entrada, cabe detenernos en el apodo que sus fans - particularmente los de su obra musical- le han dado a la artista y del que posteriormente, tanto sus lectores, como los propios críticos y académicos, nos hemos apoderado y en cierta medida, resemantizado. Me refiero a "La Montra".

El apodo de "La Montra", marcado de oralidad, de coloquialidad, de calle, se le otorgó a Rita Indiana en el año 2010 tras el éxito del álbum Eljuidero, que sacó junto a su banda Rita Indiana y Los Misterios, surgiendo en un contexto de conciertos y algarabías. Con este modismo, desde las canchas y las gradas, entre coreos de sus canciones y

2 Para una revisión de los diferentes estudios teórico-críticos en torno a la obra narrativa, performática y musical de Rita Indiana, véase el libro Rita Indiana. Archivos, Fernanda Bustamante (ed.), Ediciones Cielonaranja, 2017, entre otros.

3 La trayectoria artística de Rita Indiana, desde su libro Rumiantes (1998) a su cuento "Los trajes" (2017), y desde su canción "Platanito" (2005) a su último single, "El castigador" (2017), se encuentra detallada en la introducción "(Re)visitar la obra de Rita Indiana desde su irrupción", del anterior libro citado, Rita Indiana. Archivos (9-24).

4 Ante esta idea remito a la distinción que establece Meizoz -a partir del planteamiento de Nathalie Heinich expuesto en De la visibilité (2012) - entre reconocimiento y celebridad: "La celebridad visual [artística] constituye un valor contrario al reconocimiento literario por los pares, reconocimiento que se funda en el prestigio adquirido por la obra gracias al juicio especializado de los profesionales" ("Escribir" 258; cursiva del original). Para más información al respecto, véase el capítulo de Nathalie Heinich, "Créateurs er penseurs", del libro De la visibilité. Excellence et singularité en régime médiatique. 
gritos varios, se le identificó como una "artista con cualidades extraordinarias", como una "maestra", una "ídola". Sin embargo, la institucionalidad cultural y académica se ha servido de este código onomástico para articular y explicar la imagen de autora de Rita Indiana: "La Montra" (monstruo/monstruosa) implica también la noción de "desvío", de "contrario al orden de la naturaleza". En el caso de la artista, esta situación se inscribe, por una parte, en su propio cuerpo, al no responder a los estándares físicos femeninos ni al imperativo heterosexual (véase Wittig); y por otra, en su propia obra, al delinear un posicionamiento artístico contradiscursivo:

Apodada "La Montra", la escritora, artista y cantante dominicana Rita Indiana Hernández [...] ha conseguido hacer de la monstruosidad un recurso que desestructura las oposiciones binarias, los esencialismos identitarios y las diferencias fundadas en la corporalidad y en las lecturas normativas de la sexualidad. Desde el mismo acto de su reconocimiento y autolegitimación como "monstruosa", Rita Indiana pone a tambalear las prácticas regulatorias a partir de las cuales se materializa la feminidad, y desarticula la misma normatividad en la que se sostiene la diferencia sexual, pero además la misma condena con la que ha sido definida, desde por lo menos el siglo XIX, la creatividad y autoría de las mujeres. (Vera-Rojas 209) ${ }^{5}$

Este nombre asignado por sus seguidores para identificarla funciona como una pieza fundamental del entramado autorial de Rita Indiana y nos lleva a la relación entre autoría y corporeidad. Esto se debe a que su imagen de autora está triplemente anclada al cuerpo: por ser una escritora/artista mujer, por ser una escritora/artista mujer en un cuerpo andrógino, y por ser una escritora/artista mujer en un cuerpo andrógino lésbico. Tal como iremos observando, en el caso de la autora se presenta un evidente rechazo a la denostación de su cuerpo, para en su lugar -y mediante una "tecnología del yo" (Foucault, Tecnologías) - optar por visibilizarlo y hacerlo partícipe de la imagen autorial que ha ido construyendo, lo que ha implicado, a su vez, que el cuerpo mismo de Rita Indiana forme parte de su obra.

Tanto en la esfera literaria como musical, su postura política de resistencia, que apela a una subversión y reordenamiento de los márgenes identitarios (individuales y nacionales, corpóreos y geográficos), ha ido de la mano de su abierta homosexualidad y de su apariencia física, en la que ha acentuado su aspecto andrógino a partir de artificios estilísticos (como llevar el pelo corto y vestirse con trajes "masculinos"). Estos rasgos, o piezas de la autora, nos dejan entrever cómo Rita Indiana en su obra y en su propia autorrepresentación socava y se burla de los parámetros de la masculinidad y feminidad.

Para otra lectura del apodo "La Montra" desde una visión de género, véase Hutchinson (351); y de su apodo en torno a lo monstruoso como crítica a la discriminación racial, especialmente a la comunidad haitiana, véase Jaime (91).

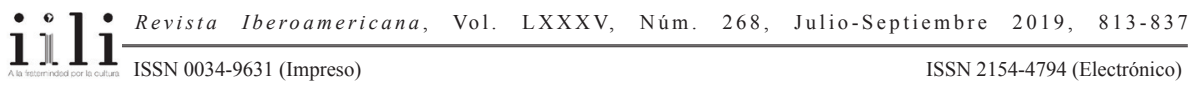


Más allá de las diferentes performances artísticas de género que ha realizado la artista - como el bigote que usaba en el escenario durante los concierto con su banda Casiful, o la caracterización del personaje de la sicaria que interpretó en el videoclip de su canción "El juidero", o su aparición en los premios Casandra de música junto a su mujer en 2010, que ya han sido ampliamente abordadas desde el enfoque de los estudios queer - en esta ocasión quiero referirme a una instancia pública puntual, más relacionada a su quehacer literario, donde Rita Indiana articuló, física y discursivamente, una autofiguración y posicionamiento de resistencia a la sexualización normalizadora. Me refiero a la gala de premiación del II Premio de Novela de la Bienal Mario Vargas Llosa entregado en abril de 2016 en Perú, de la que resultó ganador el chileno Carlos Franz por Si te vieras con mis ojos (2016). ${ }^{6}$

Rita Indiana fue finalista del premio con su novela La mucama de Omicunlé(2015) -probablemente el premio de literatura más importante en el que ha participado hasta ahora la autora y de mayor repercusión internacional-. ${ }^{7}$ En esa oportunidad destacó no solo por ser la más joven, por ser la suya la única novela de ciencia ficción nominada, que como señaló la propia autora, era la única novela con el acontecer puesto en el futuro y no en el pasado de la región; sino que principalmente por ser la única mujer. Este hecho no dejó de sorprender dado a la fuerte presencia de escritoras -algunas más consagradas que otras-, en el actual panorama literario latinoamericano. En vista de ello, en el marco de esa actividad, hay dos gestos de Rita Indiana que se inscriben dentro de los actuales soportes de exhibición de los artistas, y que están al servicio de la representación de su figura autorial -como son la entrevista publicada en un medio escrito y la participación en un acto público con cobertura mediática-, en los que lo manifestado en su propio discurso, junto a la propia corporalidad de su cuerpo enunciante, dan cuenta de su postura autorial (Meizoz, “QQué entendemos?”).

En una entrevista dada al diario oficial El Peruano días antes de la premiación Rita Indiana declaró: "Soy una anomalía para la literatura de América Latina. Acá parece que para ser escritor se debe ser hombre, blanco y heterosexual" (en Chichizola s/p). Vemos cómo mediante estas palabras la artista se legitimaba como La Montra, esta

6 En torno a los estudios críticos centrados en las performances artísticas de la autora y su obra narrativa, desde una lectura queer, véanse los artículos de Rivera-Velázquez, Vera-Rojas y Torrado, entre otros.

7 Los finalistas de este premio, junto a Rita Indiana, fueron: el colombiano Juan Gabriel Vásquez (1973) por La forma de las ruinas (Alfaguara), el mexicano Héctor Aguilar Camín (1946) por Adiós a los padres (Penguin Random House), el peruano Renato Cisneros (1976) con La distancia que nos separa (Planeta), y el chileno Carlos Franz (1959) por Si te vieras con mis ojos (Alfaguara), quien fue el ganador del premio. El jurado estuvo comprendido por: el director de la Real Academia Española (RAE), Darío Villanueva, el escritor peruano Alonso Cueto, el editor y crítico literario mexicano Gonzalo Celorio, la hispanista y ensayista sueca Inger Enkvist y el crítico literario ecuatoriano Will H. Corral. Cabe recordar que la bienal reunió a más de 30 escritores hispano e iberoamericanos que participaron en conferencias y mesas redondas.

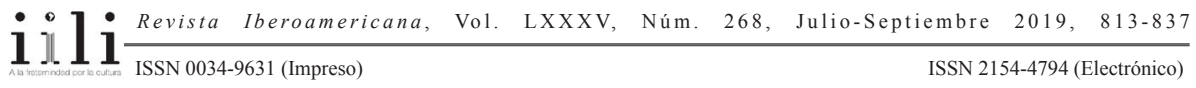


vez en el ámbito de las letras, al afirmar, desde su condición de mujer homosexual blanca, su contradiscursividad ante el establishment cultural y literario, para al mismo tiempo criticarlo. A estas declaraciones, que marcan su postura autorial, se le suma el atuendo escogido para presentarse a la gala de premiación, con el que reafirmó este posicionamiento: un traje negro de pantalón y chaqueta con camisa blanca de cuello mao.

Si bien no es una sorpresa verla vestida de esa forma, dado que es el estilo que ha solido llevar desde que tenemos nociones de ella en público, en ese contexto sí cobra mayor significación como un gesto/postura autorial, dado que al aparecer junto a los otros finalistas del premio (Juan Gabriel Vásquez, Héctor Aguilar Camín, Renato Cisneros y Carlos Franz), que vistieron de manera similar, la distinción de su género se difuminó. Es decir, es una instancia que no solo muestra cómo la artista ha inscrito en su propio cuerpo una política de desestabilización del género y las identidades sexuales, sino que también, se burla y pone en tensión las narrativas patriarcales dentro de la propia institución literaria. ${ }^{8}$

Paralelamente, en el caso de la imagen de autora de Rita Indiana participa también otro recurso de la dimensión onomástica: su firma. En la media en que el nombre inscrito en la cubierta/portada de los libros no solo funciona como huella real de un autor empírico, como ligadura de la obra con su fuente de enunciación (Derrida s/p), confiriéndole valor y autoridad a la obra misma, sino que además activa "representaciones que contribuyen a la imagen de autor" (Maingueneau 25). En este sentido, no es insignificante que desde su primera publicación, Rumiantes (Riann ediciones, 1998), hasta la primera edición de su novela Papi (Vértigo ediciones, 2005) la autora haya firmado sus libros usando su apellido paterno, Hernández; y que desde el 2011 a la fecha comenzara a usar solamente sus dos nombres. Si bien el origen de su nombre compuesto, ya de tradición familiar, ha sido explicado por la propia artista -quien ha señalado que proviene de la unión del nombre Rita con el apodo "Indiana" de su bisabuela, que era mulata, y cuyo esposo la llamaba así "porque era oscura", usando el término "indiana" para establecer una relación entre su color de piel y el de los indígenas y los mulatos-, la decisión de eliminar su apellido, asumiendo una nueva identidad enunciativa, entrega otro componente a su figura autorial:

There's a little story behind that. It's actually my middle name, my given middle name. My name is Rita Indiana Hernández Sánchez, y ese nombre, it was my greatgrandmother's name, Rita Indiana del Castillo. And I'm the third Rita Indiana, so it's

\footnotetext{
En vista que la fotografía y su publicación funciona como otro dispositivo visual de figuración autorial, si atendemos también a las diferentes fotografías para las que posaron juntos esa tarde los finalistas del premio, se vuelve a reafirmar la postura de Rita Indiana. Destaco en este punto las fotografía que aparecen en las columnas "El español en cinco libros" de Raúl Tola, en El País; y "Rita Indiana: prueba de que los tiempos están cambiando y también la literatura" de Antonella Chichizola, en Altavoz, ambas disponibles en internet.
}

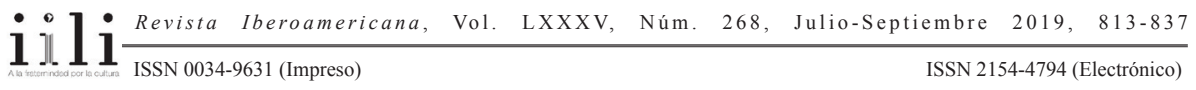


more than given, it's a family tradition. The fact is that the first Rita Indiana, her name was Rita, but she was mulatto and her husband called her Rita Indiana because she was dark. So when they had a grandchild, mi bisabuela que era la nieta de esta mujer le puso el nombre y el apodo, Rita Indiana, esa fue la segunda Rita Indiana, entonces mi bisabuela, y cuando yo nací, me pusieron el nombre de ella, Rita Indiana. (Rita Indiana en Morales s/p)

Más allá de la evidente distancia que se toma - por diversos motivos personalesde la figura paterna, al elidir su apellido Rita Indiana construye un nueva pieza de su puesta en escena autorial que le da autenticidad en un doble sentido, ya que mediante este nuevo signo de identificación no solo corrobora su autoría y el ser la responsable de las respectivas creaciones, sino que reafirma su singularidad, su unicidad. Sin embargo, a este factor hay que agregarle el entramado metafórico que hay en esta denominación. Teniendo en cuenta la propia explicación dada por la autora, su segundo nombre, visto como adjetivo, se inviste de una carga racial e histórica que cobra protagonismo al dejar de ir acompañado del apellido. Así, su nombre como símbolo pasa de plasmar una tradición familiar a una historia regional, es decir, se asume como una efigie que encarna a su vez un relato cultural. A partir de su firma la autora hace visible esas subjetividades otras -las comunidades indígenas, afrodescendientes, mulatas...-, esos cuerpos racializados excluidos de los imaginarios nacionales, así como también de los imaginarios institucionales, intelectuales y culturales hegemónicos. De esta forma, al poner en diálogo la firma de Rita Indiana con su cuerpo -y con la genealogía de ese cuerpo, un cuerpo blanco que fisiológicamente no heredó esa oscuridad, un cuerpo que opera como evidencia del blanqueamiento-, podemos desprender una nueva propuesta/ postura autorial: establecer un rechazo a la amnesia histórica y a esos presupuestos identitarios oficiales fundados en una hispanofilia, para asumir, y al mismo tiempo apelar, a una reivindicación de que en la isla todos llevan "el negro tras la oreja" remitiendo aquí a los versos del poeta dominicano Juan Antonio Alix (1883-1918). ${ }^{9}$

Por tanto, a partir de esta firma -de la que no podemos negar tampoco que funciona como marca- el claro reconocimiento visual de Rita Indiana logra un reconocimiento nominal, con lo que su nombre pasa a unificar su obra en un cuerpo que encarna polifonías de género y raza, inscritas corporal y discursivamente. Estas polifonías que la autora celebra, sin lugar a dudas, contribuyen en la composición de su autoría.

9 Por otro lado, dialoga también con este discurso/postura de la autora la ubicación que señala en su perfil de Twitter, donde indica Las Antillas, y no República Dominicana, o Puerto Rico, donde reside actualmente, con lo que se da cuenta de cómo la artista se sirve de la ambivalencia de ese dato del perfil -que identificamos con ese logo de ubicación, pero que deja abierta la interpretación al lugar donde se vive actualmente, al lugar donde se nació (o de donde se es)- para indicar más bien la zona de donde se siente parte, o desde donde emerge su enunciación atendiendo a los vínculos, diálogos y elementos en común entre los diferentes países de la región antillana. 
En vista que la construcción de la imagen de autor atiende también a los elementos situacionales, cabe señalar asimismo que el momento de este cambio de nombre en su labor literaria es relevante ya que fue en 2011, tras firmar contrato con la editorial Periférica, es decir, cuando su carrera como escritora daba el paso a la internacionalización con la tercera edición de su novela Papi (2005), esta vez bajo el sello español. De esta forma, su firma de Rita Indiana Hernández quedó vinculada a ese período en que su obra literaria se difundía por circuitos más reducidos e íntimos del propio Caribe y sus cercanos, a ese período en que aún era una desconocida, en que aún no entraba en la escena literaria. Sin embargo, el 2011 fue un año de inflexión en su carrera: la crítica literaria le dio una muy buena acogida a su novela Papi-cuya primera edición, que había pasado prácticamente inadvertida, había salido seis años atrás-; el álbum El juidero (2010) de Rita Indiana y Los Misterios, junto a los respectivos videoclips y conciertos varios, obtuvieron un éxito y repercusión internacional insospechado: ${ }^{10}$ y además el periódico El País la seleccionó como parte de las 100 figuras latinas más influyentes. Es decir, fue un año de cobertura mediática y de consagración de su imagen como una celebridad.

Sin embargo, como era de esperar, las consecuencias de este crecimiento de su carrera musical, la fama y exposición llevaron a Rita Indiana a anunciar su "retiro" o "abandono" de los escenarios musicales para dedicarse de lleno a la escritura. ${ }^{11}$ Así lo comunicó en diferentes ocasiones a lo largo de estos años: "Mi último concierto lo di en Barcelona en septiembre de 2011. No pienso volver a hacerlo" - dijo para la revista Harper's Bazaar, en enero de 2013 ("Adiós al merengue" 93)-. Asimismo, el 17 de diciembre de 2013, para una entrevista del periódico dominicano Cambio 16 diario digital, ante la pregunta de si la Rita Indiana escritora haría descansar por una temporada a la Rita Indiana cantante y compositora, la autora respondió: "Espero que la haga descansar en paz, es decir, que la sepulte" ("Rita Indiana escritora y cantante" $\mathrm{s} / \mathrm{p}$ ). En esta misma línea fueron sus declaraciones en una entrevista para el medio ZONAR.L. TV, el 13 de septiembre de 2014 en Bellinzona (Suiza), donde se encontraba participando en el Babel Festival Internacional de Literatura y Traducción, donde señaló: "Desde el 2011 dejé la música porque no podía bregar con la fama y la jodienda y el afoque [...] y me he dedicado a lo que me dedicaba antes que es la literatura" ("Rita Indiana en ZONA R.L. TV" s/p).

${ }^{10}$ El álbum fue nominado al premio Casandra en 2010 por Revelación del Año, y en 2012 por Video Clip del Año con el video de "Da pa' lo' do"'. Asimismo la banda realizó varias giras, pasando del escenario del Hard Rock Café Santo Domingo, a festivales como el BAM (Barcelona Acción Musical) y SummerStage, en la gran manzana de Nueva York; y tres canciones del disco cuentan con videoclip: "El juidero", "La hora de volvé" y "Da pa' lo' do"".

${ }^{11}$ De hecho, el mismo 2011 dejó de publicar en su Facebook, en su "maldito feibú", remitiendo a su canción.

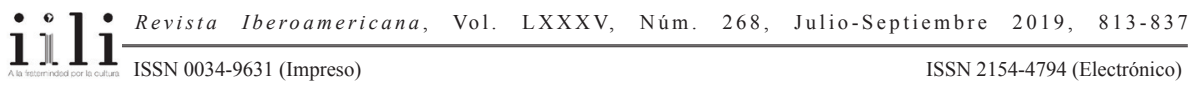


Así, desde 2012 su participación pública estuvo enmarcada en diversos encuentros internacionales, literarios y académicos, donde participó con lecturas de sus obras y conferencias principalmente en torno al estado de las letras recientes del Caribe y las temáticas LGBTQ, que, como tales, no han recibido la misma atención ni cobertura mediáticas, por lo que su rostro y su voz - su imagen- pasaron a escenificarse en espacios más restringidos. Vemos, por tanto, cómo esta idea/postura de dejar atrás a su autoría como cantante para darle protagonismo y exclusividad a su autoría literaria, determinó su quehacer artístico de esos años. ${ }^{12}$

De hecho, esos años fueron clave en su reconocimiento como escritora, entre otras cosas porque sus dos últimas novelas participaron en certámenes literarios: Nombres y animales (2013) fue nominada al IV Premio Las Américas de Novela en Puerto Rico; ${ }^{13}$ y La mucama de Omicunlé (2015) la llevó nuevamente a estar entre los finalistas de ese premio, esta vez en su séptima edición. ${ }^{14}$ Asimismo, tal como ya hemos comentado, esta novela fue finalista de la II Premio Bienal de Novela Mario Vargas Llosa; y además, en abril de 2017, la hizo merecedora del Premio Literario de la Asociación de Escritores del Caribe, que por primera vez se entregó a un escritor hispanohablante. ${ }^{15}$

Observamos, por tanto, una reconfiguración en la imagen de autora de Rita Indiana durante este período, en el que su consagración narrativa, ahora con más bajo perfil mediático, ha implicado también una actitud más silenciada tanto en los medios masivos de prensa, como en sus propios dispositivos de autofiguración en las redes sociales. De hecho, junto con dejar de publicar en su Facebook el 2011, su Twitter no se ha caracterizado precisamente por publicar asuntos autorreferenciales ni vinculados a su

12 Debo aclarar que con dejar atrás a la música me refiero a los escenarios dado que, tal como la propia Rita Indiana ha señalado, continúa con proyectos musicales: "voy a hacer proyectos más experimentales, más instrumentales, no tanto con mi cara y mi baile al frente. Estoy escribiendo guiones para películas, voy a hacer música para películas también" (Rita Indiana, "Entrevista a Rita Indiana” s/p). Además, en 2014 estrenó su serie documental Playa vida, creada y producida por la autora, quien también compuso la música del programa puertorriqueño.

13 En esta edición del premio, que se concede en el marco del Festival de la Palabra de Puerto Rico, los nominados junto a Rita Indiana fueron: el colombiano Juan Cárdenas con Los estratos, el mexicano Yuri Herrera con La transmigración de los cuerpos, y la peruana Claudia Salazar Jiménez con La sangre de la aurora, que resultó la ganadora.

14 Los finalistas del premio, junto a Rita Indiana, fueron: el mexicano Emilio Monge con Las tierras arrasadas y la catalana Ariadna Castellarnau, con Quema, que fue la ganadora.

15 Los otros finalistas hispanohablantes fueron: los venezolanos Rodrigo Blanco por The night, Israel Centeno por La Marianne, Juan Carlos Mendez por Y recuerda que te esperó, Fleján Salvador por Tardes felices: crónicas pop apocalípticas, Natasha Tiniacos por Historia privada de un etcétera, José Urriola por Santiago se va; el colombiano Fernando Fernández por Soledad publicas, el cubano Leonardo Padura por Aquello estaba deseando ocurrir, la puertorriqueña Mayra Santos Febres por La amante de Gardel, el panameño Carlos Winter por Las impuras y el peruano Luis Yslas por $A$ la brevedad posible.

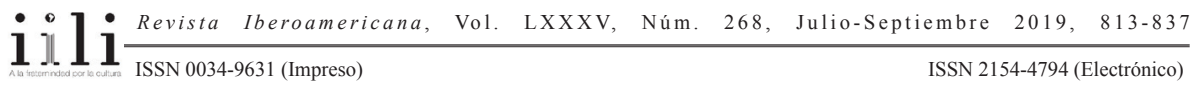


producción artística. ${ }^{16} \mathrm{Al}$ contrario, en él se pueden identificar un reducido número de post en torno a sus novelas y los premios recibidos, por ejemplo: uno que otro link que dirige a sitios de venta de sus libros, y los anuncios de sus nominaciones. Incluso, no deja de ser sorprendente su actitud al ganar el premio en el Caribe, retwitteando un par de veces la noticia de su premio y expresando su agradecimiento con escuetas palabras: "Muy agradecida y emocionada"(@RitaIndiana 10 de abril 2017).

Sin embargo, esta postura más reservada y de menos euforia, que muestra el control de la autora sobre su propia imagen -y que responde en gran medida al aprendizaje adquirido durante estos años de exposición y a su propia maduración-, compete al yo autorial de Rita Indiana en relación a su obra artística literaria y su respectiva recepción, pero no a su voz en otros ámbitos, ya que sí mantuvo una participación activa en las redes sociales y medios, solo que en otro espacio autorial. Desde octubre de 2013 hasta marzo de 2016, la tribuna de Rita Indiana estuvo en dos medios digitales de prensa: la revista venezolana Prodavici y el diario El País, en los que publicó simultáneamente, y con una entrega prácticamente mensual, breves columnas -que, como es evidente, tuvieron mayor impacto en cuanto a la recepción en el medio español-. ${ }^{17}$

Esta nueva faceta en la escritura en prosa de Rita Indiana-inscrita en una composición textual identificada como híbrida y polimorfa (véanse Rotker, Villoro, Carrión) y que se relaciona estrechamente con las llamadas "literaturas del yo"- mantuvo bastante proximidad con sus textos de ficción ya que en sus columnas también conviven y dialogan sus intereses estilísticos con sus preocupaciones por las problemáticas sociopolíticas y culturales e identitarias, tanto de la realidad dominicana como internacional, sin abandonar su estilo escritural, donde el sarcasmo, la intertextualidad y los juegos metafóricos son fundamentales. Así, nos encontramos con escritos que se podrían vincular con textos de crítica cultural en los que la escritora, desarrollando un tono autorial apreciativo estético - mas no por ello desideologizado-reflexiona en torno a diferentes producciones recientes (literarias, cinematográficas, musicales, junto a televisivas y de videojuegos). Pero, paralelamente se encuentra otro conjunto de sus columnas, que atienden a un presente convulso, en las que presentó y problematizó un hecho de la actualidad bajo un tenor testimonial, por lo que puso en escena a su "yo" no solo como narradoraautora, sino también, en gran parte de las ocasiones, como protagonista de lo narrado, sin ningún tipo de tapujo. Es precisamente en estos textos de corte sociocultural de Rita Indiana donde cobran sentido su firma nominal y esa resistencia de todo cronista

${ }_{16}$ Es necesario señalar que para efectos de este artículo se contemplan las publicaciones realizadas por la autora en las redes sociales hasta noviembre de 2012.

17 La autora publicó las mismas columnas en ambos espacios y en las mismas fechas. Estas están disponibles en: $<$ http://prodavinci.com/?s=rita+indiana\&imageField. $\mathrm{x}=9$ \&imageField. $\mathrm{y}=12$ \&imageField=Search $>\mathrm{y}$ $<$ http://elpais.com/autor/rita_indiana_hernandez/a $>$.

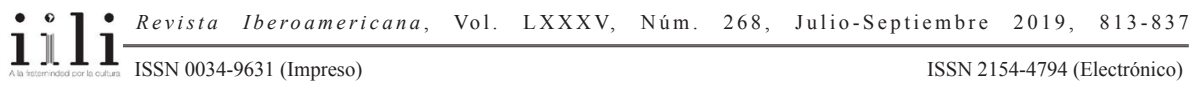


a elaborar relatos aislados de la subjetividad (véanse Caparrós, Chillón), ya que están atravesados por reflexiones ideológico-políticas y por un marcado tono de denuncia y crítica social. Acudir a este género escritural, que se ha caracterizado por dar espacio a la delación, se constituye como otras de las piezas clave en su composición de imagen autorial y postura de autora.

En este tipo de columnas, Rita Indiana arremetió contra la izquierda latinoamericana contemporánea de "vocación dictatorial", contra la falta de libertad de expresión en Cuba, y contra la complicidad y colaboración del gobierno mexicano con el narcotráfico. De la misma forma, la política nacional de República Dominicana fue blanco de sus escritos, en los que en varias ocasiones denunció la corrupción, el clientelismo, la demagogia y la impunidad del cuerpo político dominicano. ${ }^{18} \mathrm{Y}$, como era de esperar, un importante número de ellas tuvieron como centro las problemáticas relativas a la discriminación de raza y de género.

Todas sus colaboraciones relacionadas con la discriminación racial dominicana estuvieron motivadas tras la controversial sentencia TC/168/13 del Tribunal Constitucional de la República Dominicana en octubre de 2013, con la que se dictaminó el despojo de la nacionalidad dominicana a todos aquellos hijos de extranjeros en tránsito, nacidos en el país a partir de 1929, y por la consecuente aplicación de la política de deportación en 2015. Así, en sus artículos "Magia negra” (9 de octubre de 2013), "Tu afro no cabe en la foto" (29 de julio de 2014), "El problema haitiano" (3 de marzo de 2015), "El éxodo apátrida" (7 de julio de 2015) y "República Dominicana, chivo expiatorio" (17 de agosto de 2015), Rita Indiana denuncia cómo la orden dictada por el gobierno dominicano perpetúa el racismo despiadado que se ha tenido a lo largo de la historia con los inmigrantes del país vecino, y cómo al aplicar esta resolución política al derecho, se instaura el racismo como ley. La autora critica abiertamente a los discursos xenófobos dominicanos, y a las instituciones gubernamentales por legitimar esos relatos de identidad nacional fundado en ideas de un pretendido blanqueamiento y negación del componente negro. Esto deja entrever una actitud/postura de la artista en la que se niega a preservar la retórica del odio y autodesprecio, así como a la subalternización del haitiano promulgada por las autoridades del gobierno y tan enquistada en la conciencia nacional. De esta forma, es interesante su última columna, "República Dominicana, el chivo expiatorio", ya que es la única sobre ese tema en la que Rita Indiana afirmó cómo se sirvió de esa modalidad de escritura para expresar abiertamente su posicionamiento ante la actuación del gobierno:

${ }^{18}$ Me refiero, por ejemplo a las columnas: "Inmunológica" (4 de marzo de 2014), "Bad trip" (26 de abril del 2014), "Ayotzinapa: más acción y menos literatura" (2 de diciembre del 2014), “Je suis' Tania Bruguera" (10 de febrero del 2015), "La mala educación" (24 de marzo del 2015), "La dictadura del No Ha Lugar" (5 de mayo del 2015), entre otras.

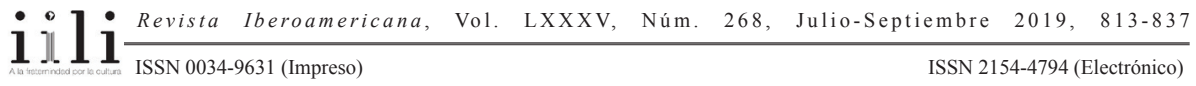


En varias ocasiones he utilizado este espacio para exponer las injusticias que se cometen contra la comunidad haitiana en mi país. [...] Este patético panorama [...] ha sido la razón por la que Dominicana lleva más de un año siendo el blanco de la crítica de la comunidad internacional y de artistas e intelectuales (me incluyo) que han tachado de racistas las políticas migratorias que se ponen en práctica actualmente para enfrentar el problema haitiano. (s/p; cursivas personales)

Un enfoque/postura de autora similar tuvieron sus columnas vinculadas a la comunidad LTBQ, ya que en ellas también se plasma ese intento por visibilizar la precariedad y vulnerabilidad de los cuerpos inaceptados, solo que esta vez desde las identidades sexuales alternativas. Sin embargo, estos textos la autora los abordó desde un "yo" narrativo que, con diferentes tonos emocionales, hizo público experiencias privadas e íntimas, para desde ahí apelar a un reconocimiento, por lo que entregan otros componentes en lo que compete a la construcción de una imagen autorial. En sus columnas "Disney gay" (21 de octubre de 2014) y "Los valores familiares de Cartoon Network" (20 de octubre de 2015), se nos presenta un yo autorial construido desde el Rita Indiana yo-que-fui-niña-y-adolescente-gay, y el Rita Indiana yo-madre homosexual, que valora ciertos gestos en los medios por desnaturalizar y rectificar las normas heterosexistas. Sin embargo, destacan dos columnas en los que la autora apela a la legitimación del deseo-otro, de ese afecto condenado a la disidencia, transformando a su propia experiencia vivida en material de escritura, por lo que son textos en los que desde la exhibición de su propio dolor y aflicción clama por la autodeterminación de esas subjetividades precarias. Por un lado, en "Matrioskas en la cancha" (27 de mayo de 2014) Rita Indiana plantea que el acto de decir-se abiertamente homosexual, esa "salida del clóset", no es única, sino que perdura en el tiempo ante cada sociabilización, con lo que da cuenta de cómo estas subjetividades se han visto forzadas a tener que asumir el constante y reiterativo sometimiento a situaciones de dolor y enjuiciamiento: "Tras abrir la puerta de armatoste de caoba en el que viví mi mayoría de edad [...] me hallé saliendo de un closet nuevo todos los días" - dice Rita Indiana ("Matrioskas en la cancha" s/p; cursiva del original). Asimismo, en "Vida gay 1: tomar tu mano" (28 de julio de 2015), abordado con mayor implicación emotiva, y acudiendo a una modalidad de escritura diferente, mediante el apelativo "tú", que remite a su pareja, la autora explica cómo ese soltar la mano de su amada en público, ya automatizado, es una acción forzada por las violentas miradas de los otros que recriminan y sancionan el deseo homosexual, condicionándolo a lo impensable e indecible. Así, en esta columna se nos presenta una nueva voz autorial, ya no solo con una postura de crítica y resistencia, sino que también muestra una imagen de autora en condición de vulnerabilidad donde las emociones de tristeza, miedo y dolor son exhibidas desde su propia intersubjetividad:

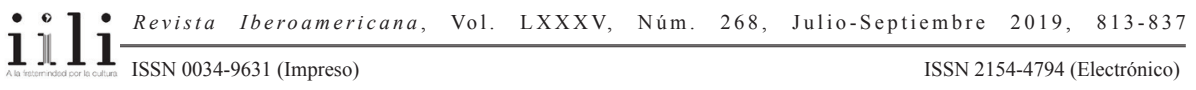


Pero el miedo llega [...]. Retiro mi mano temerosa de otras que hacen señas obscenas en los balcones y que lanzan, desde allí, un envase de leche podrida o una llave inglesa contra mi cabeza. Manos de señora o de joven, manos que tienen agarrado por los cojones el desempeño afectivo de las mías.

Esta reacción es ya en mí un reflejo inmediato. No es que sea cobarde. Conozco el estrujón que hace en la tarde un insulto homofóbico y quiero evitarte el mal momento. Retiro mi mano para que nuestro paseo genere el menor odio posible. ("Vida gay 1 "s/p)

Podemos señalar, por tanto, que la experimentación de Rita Indiana en este nuevo género discursivo -ya no ficcional ni exclusivamente artístico, sino que propio del ámbito periodístico-, se conforma como otro espacio/escenografía desde donde construir su imagen de autora, y que, junto con diversificar a su público y receptores, le permitió expresarse desde su propia subjetividad y exponer su postura autorial desde otra vertiente del campo cultural, ya no solo vinculada al ámbito creativo. Por ende -y siguiendo a Butler-, pasan a ser escritos en los que la autora, consciente de lo mediático de sus palabras, apela por visibilizar el dolor -ajeno y propio-, y así "transformar el dolor en un recurso político" (57).

Asimismo, en lo que se refiere al tono autorial, en estas columnas de opinión, de corte más sociopolítico, la voz de Rita Indiana pareciera irrumpir desde la indignación, la molestia e incluso el dolor, emergiendo una escritura desafiante e interrogante. En ellas la autora interpela a las narrativas que condenan a esas subjetividades a reprimir sus afectos y a ocultar sus rostros, y reclama por la reivindicación de la integridad de esos cuerpos-otros en condición de vulnerabilidad y precariedad, por los derechos a la autodeterminación, así como por la necesidad de desmantelar la noción hegemónica de "dominicanidad". De esta forma, nos encontramos ante unos textos con una clara voluntad/postura política, en los que se logra delinear una imagen de autora militante y concientizadora. Es decir, la Rita Indiana de estas columnas se vendría a vincular con lo que Jérôme Meizoz denomina como la postura del escritor-ciudadano, entendido como el escritor "comprometido, que recurre al profano (esto es, al público general) para legitimar sus tomas de posición más allá del medio literario” (“QQué entendemos?”197).

Sin embargo, cabe prestar particular atención a la dimensión sociotópica de estas columnas (Diaz, "Las escenografías" 160) ya que Rita Indiana hizo estos enunciados desde un lugar concreto. No es insignificante que la autora se haya pronunciado en dos medios de comunicación periódicos y digitales no dominicanos -sobre todo si pensamos que la contingencia dominicana y haitiana no suelen protagonizar las páginas de los medios internacionales-. Pero no solo porque la circulación mediática es mayor y por tanto los receptores pueden llegar a ser más numerosos y más heterogéneos en sus realidades socioculturales, o porque podría exponer más abiertamente su oposición y crítica a las diversas políticas, sino porque el impacto informativo es mayor, y por ende, la visibilización de su figura de autora también lo es. Es decir, hay una estrategia 
de autofiguración y autopromoción de su imagen autorial que es relevante si se piensa que Rita Indiana no se decantó por publicar exclusivamente en un medio alternativo venezolano, sino que optó por compaginarlo con uno de los periódicos de mayor difusión en el ámbito hispanoamericano, y donde un importante número de escritores conforman su lista de colaboradores, por lo que le permitió también posicionarse dentro de esa esfera del campo cultural.

Ahora bien, si atendemos a la idea de que la postura literaria identifica al autor/a en el campo pero que al mismo tiempo “delimita el horizonte de recepción” (Meizoz, ¿Qué entendemos?" 203), esta estrategia de visibilidad mediática ha tenido sus perjuicios en Rita Indiana, ya que la abierta exposición de sí misma y de su posicionamiento ideológico le ha significado enfrentarse a refractarios tanto del público general como del perteneciente a la propia institucionalidad cultural y política dominicana. Esta situación, sumado al hecho de ser una mujer-escritora-lesbiana en una sociedad patriarcal y heteronormativa, podría explicar en alguna medida la escasa presencia de su obra en República Dominicana, su prácticamente nula participación en actividades literarias organizadas por los organismos públicos, o el que no se le haya reconocido con ningún premio literario en su propio país. De hecho, la misma autora, en una entrevista en el marco del II Premio de la Bienal Mario Vargas Llosa, lamentó que sus libros no fueran difundidos en República Dominicana y dio como explicación que la "consideran una traidora por defender a los descendientes haitianos" tras sus opiniones expresadas en las respectivas columnas ("Rita Indiana: "Mi literatura es una bomba"” s/p). ${ }^{19}$

Vemos, por tanto, cómo durante esos años (2013-2016), en los que Rita Indiana fue consagrándose en el panorama literario latinoamericano, sus columnas periodísticas o columnas de opinión le permitieron experimentar en un nuevo espacio público de autofiguración, en el que dejó de ponerse a sí misma en escena simplemente como narradora o música, y pasó a vincular su imagen de autora disidente y contestataria a la figura del humanista, del intelectual comprometido.

No obstante, y tras casi un año de silencio e invisibilidad mediática, en el que quizás su actividad pública más relevante fue su asistencia al VII Congreso Internacional de la Lengua Española celebrado en Puerto Rico -donde participó, junto a los escritores boricuas Juan López Bauzá y Luis Negrón, en la mesa “¿Cómo escribe el Caribe?”, y adelantó que entre sus proyectos se encontraba una próxima novela, de corte más histórico-político, que por el momento lleva por título Los trajes-la reaparición de Rita Indiana en la escena artística el 2017, después de siete años alejada de los espectáculos multitudinarios, trajo consigo tanto la reactivación de su figura como celebridad, como

19 A la fecha entre las actividades oficiales gubernamentales solo se registra la participación de Rita Indiana en la XII Feria Internacional del Libro de Santo Domingo de 2009, en la que se le dedicó un día a la autora. Es decir, antes que comenzara su internacionalización a nivel literario y que se decretara la nueva ley de inmigración en el país.

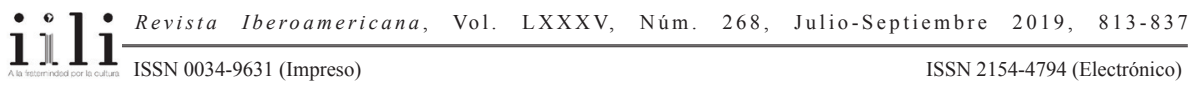


la reactivación de su postura como artista comprometida. Ante esto, cabe prestar atención a una serie de dispositivos y estrategias discursivas de este supuesto regreso, al contexto social y los factores tecnológicos y mediáticos, que no solo contribuyeron al éxito de su nueva pieza musical sino sobre todo a la legitimación de su imagen autorial.

Los primeros días de marzo de 2017 se hizo pública la presencia de Rita Indiana en el Festival Isle of Light en Santo Domingo, noticia que no dejó de sorprender a su fanaticada que había creído en esa sepultura de la Rita Indiana cantante. ${ }^{20}$ Casi más inesperado aún resultó ser, a solo tres días del concierto, el lanzamiento de su nuevo single, "El castigador", junto al estreno del videoclip el 29 de marzo en las redes. Ambas situaciones fueron anunciadas por la propia artista y la directora del video la noche anterior desde sus respectivos Twitters. Esto no solo generó gran expectación en los medios y sus seguidores, sino que, al haberse construido como un acto de enunciación que sigue el propio estilo de los post, mediante la utilización del hashtag, Rita Indiana adelantó en gran medida tanto el contenido de la canción como la postura autorial con la que regresaba: "Hoy a la media noche compartiré con ustedes mi nuevo sencillo y video ‘ElCastigador’[...]@CeroImpunidadRD”(@RitaIndiana,29 de marzo de 2017); "Esta noche a la media noche lanzamos el video de mi nuevo sencillo \#elCastigador dirigido por la gran@maoherencia por el \#FinDeLaImpunidad" (@RitaIndiana, 29 de marzo de 2017).

Las etiquetas utilizadas por la autora,\#FinDeLaImpunidady@CeroImpunidadRD, funcionan no solo como una afirmación de reclamo, sino que también de adhesión a un movimiento puntual. Esto se debe a que a fines de enero de 2017, tras hacerse público el caso Odebrecht - uno de los casos más emblemáticos de la historia contemporánea dominicana de escándalos de sobornos, blanqueo de capitales, en el que se han visto involucrados exfuncionarios de gobierno y empresarios- se convocó a una marcha contra la impunidad política para solicitarle al presidente dominicano, Danilo Medina, la realización de una auditoría y apertura de la investigación del caso para someter a la justicia a todo el entramado delictivo. A solo un mes de esta protesta, y ante el silencio de la clase política gobernante se creó la asociación Marcha Verde que convocó a nuevas manifestaciones en diferentes ciudades del país, sacando a la ciudadanía del letargo y poniéndola nuevamente en la calle, pero esta vez llevando alguna prenda

${ }_{20}$ De hecho, y como parte de esa atmósfera de revisitación, se publicó el 24 de marzo en la revista digital Discolai, dirigida a la música alternativa de República Dominicana, “Dios Salve a la Montra': 6 reversiones de Rita Indiana que debes escuchar", donde se muestran esas "reverencias/reversiones", poco conocidas, que durante los últimos años diferentes músicos le hicieron a modo de tributo, funcionando a su vez como otra instancia de reconocimiento y prestigio artístico de su figura de artista. Estas versiones o covers son: "La Sofi" de Julieta Venegas y Ceci Bastida, "Da pa' lo' do"” de River Tatem; "El blu del ping pong" de Aleix Ferreira, "Como un ladrón en la noche" de Baron Janvier, "Platanito" de Lido Pimienta y "Oigo voces" de Mima. Véase en $<$ https:/discolai.com/2017/03/24/dios-salve-a-lamontra-6-reversiones-de-rita-indiana-que-debes-escuchar/>. 
de color verde, como gesto de visibilización del reclamo nacional a terminar con la corrupción. Estas han sido las manifestaciones precedentes del movimiento Fin de la Impunidad política en República Dominicana que han llenado a las ciudades de ese color en espera de una respuesta.

En vista de este contexto, al que Rita Indiana también se adhirió en diferentes ocasiones en su Twitter, marchando simbólicamente desde sus posts, su single cobra mayor significación al abordar un tema de contingencia nacional e internacional, como es la corrupción, y al lanzarse en un momento tan oportuno. Y es que "El castigador" es una canción de corte contestatario contra la corrupción política que trasciende las fronteras de su propia isla y del propio Mar Caribe, a partir de una letra y videoclip que reactivan y desplazan al presente el violento correlato de la colonización y el consiguiente sometimiento, subalternización, precarización de los pueblos y colectivos minoritarios, tal como se plasma en su estribillo “clavo con clavo, soga con sal, to' lo' corruptos van a temblar" -cuya segunda parte, no podemos negar que perfectamente podría funcionar como grito de protesta en futuras marchas.

Pero su postura de autora, ahora con el atributo de simpatizante del movimiento Fin de la Impunidad, se hizo más explícita aún en dos publicaciones en medios digitales que salieron al día siguiente del estreno de la canción, en los que aclaró las razones de su retorno. En su propio Twitter, la artista posteó: "Regreso, como dijo un trovador, para incomodar al que vive en el confort y para reconfortar al que vive en la incomodidad \#FinDeLaImpunidad" (@RitaIndiana, 30 de marzo de 2017); al mismo tiempo que en el periódico El Espectador declaró: "No podía quedarme callada, tenía que decir algo por un canal más inmediato que la literatura" (en Peguero s/p).

Más allá de si la autora tiene intenciones reales de sacar un nuevo disco y comenzar una nueva etapa en su carrera musical, o de si su regreso es algo esporádico -motivado como en la gran mayoría de los retornos de las bandas, por asuntos económicos-, lo interesante de este acto enunciativo explicativo, donde destaca el deíctico de la primera persona, es la forma en la que Rita Indiana se presenta a sí misma, ya no solo desde una dimensión estética sino también ideológica; lo que da cuenta de cómo la autora está consciente del papel que juega en la escena artística y política y cómo su propia voz y actitud participa en la construcción de los imaginarios autoriales (Diaz, "Las escenografías" s/p). En estos discursos Rita Indiana se autorrepresenta como una figura pública que incomoda a cierto colectivo privilegiado, pero al mismo tiempo, y reconociendo la existencia de sus receptores, se asume como una autoría que alienta, que entrega consuelo y fuerza a un colectivo afligido y vulnerado. Asimismo, al señalar que no podía quedarse callada, que tenía que decir algo, vuelve a investirse ya no solo como una intelectual comprometida, sino que también consciente de una responsabilidad a la que como figura pública debe responder.

Como era de esperar este posicionamiento plasmado en los medios y en las redes sociales se consolidó en la propia performance que dio en el concierto. Rita Indiana

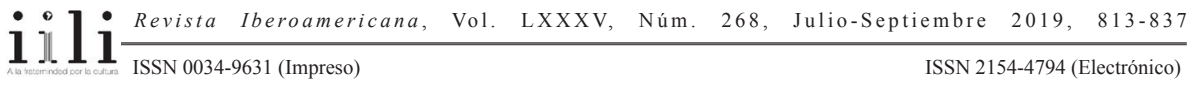


abrió su presentación en el Festival el 1 de abril con su nueva canción, que pudo ser coreada por el público gracias a esa estrategia promocional de lanzarla tan solo días antes. Pero en ese marco, destaco dos gestos autoriales en los que inscribió su postura ya anunciada en las plataformas mediáticas, que dan cuenta de cómo la postura autorial viene a funcionar también como una forma de sociabilización de la práctica artística e intelectual (Meizoz, “¿Qué entendemos?” 197). Cuando la artista cantó el verso de la canción que remite a la resistencia, al llamado colectivo a la insurrección-que dice "espíritu guerrero tu pueblo te invoca"- levantó una pañoleta verde, que luego se puso en el cuello. En ese minuto, la ovación del público se acrecentó. A esto se le suma que al terminar la canción, se acercó al micrófono y dirigiéndose a su público desde un escenario por primera vez en siete años dijo: "Estoy muy contenta de estar aquí y que nos unamos en este canto contra la injusticia y tanta cosa fea que está pasando en el país" (cursivas personales). ${ }^{21}$ Siguiendo la idea de Dominique Maingueneau, de que el ethos puede contribuir a avalar y formar modelos de comportamiento, y suscitar a la adhesión mediante maneras de decir, que son al mismo tiempo maneras de ser, podríamos decir que en este comportamiento en escena Rita Indiana, a través del uso de un símbolo identificado con las recientes manifestaciones -el pañuelo verde- y de la enunciación desde un plural inclusivo - nos unamos-, se presentó a sí misma ante el público afirmando su rechazo a ser cómplice de los discursos excluyentes, las injusticias sociales y las violencias ejercidas en diversos colectivos, pero al mismo tiempo, buscó promover en los destinatarios una adhesión a sabotear los intentos de invisiblización y silenciamiento por medio de la interpelación, corporal y discursiva, de la identificación, del reconocimiento de una experiencia y posicionamiento en común.

Vemos, por tanto, cómo Rita Indiana se sirvió del concierto, de ese otro espacio de escenificación autorial, para reafirmar y fortalecer esa imagen/postura de autora que ha ido construyendo tanto en sus performances artísticas como en su escritura ficcional y no ficcional. ${ }^{22}$

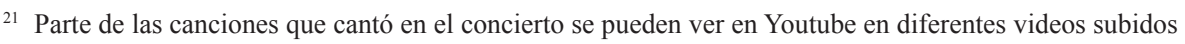
por aficionados.

${ }^{22}$ Por otro lado, cabe mencionar también en este recorrido por la trayectoria de la artista, la participación de otro dispositivo externo a la obra que dirige la lectura y recepción de estas y que contribuye en la construcción de su imagen autorial. Me refiero a la labor editorial y la elección de los elementos paratextuales y visuales de las publicaciones, teniendo en cuenta que en ese campo la obra pasa a ser una mercancía, por lo que "la imagen de la celebridad literaria es una herramienta ideológica muy efectiva para la industria editorial" (Golubov 38). En este sentido, las dos últimas publicaciones de y en torno a la artista, Cuentos y poemas (1998-2003) (Cielonaranja, 2017) y Rita Indiana. Archivos (Cielonaranja, 2017) - en las que he estado directamente involucrada como editora asociada y editora, respectivamente-, se configuran como otra pieza más de este entramado autorial. En sus portadas se observan dos imágenes de Rita Indiana que reflejan una actitud/postura/imagen de autora combativa, "rebelde", contestataria: la del primer libro es Rita Indiana llevando unos guantes de boxeo y en posición

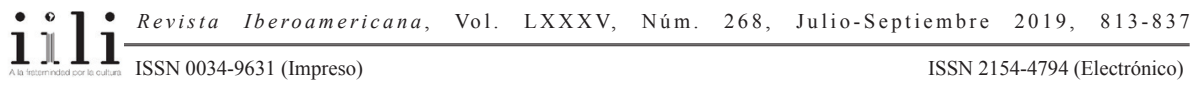


Problematizar una Autoría (Literaria, musical, intelectual) EN Proceso

Pensar en la configuración de una imagen de autor y una postura autorial en la actualidad implica concebir la noción de autor ya no solo como una identidad civil, estable y fija, fuente y autoridad de una obra, sino como un artificio cultural que se sirve de diversas estrategias de enunciación y escenificación, al mismo tiempo que es condicionado por otro entramado de dispositivos vinculados a las situaciones históricas de su producción y recepción, así como a las políticas culturales y económicas que rigen la circulación de las obras y de las propias figuras autoriales. Es decir, al analizar a un autor/a contemporáneo vivo y aún produciendo obra cabe identificar los gestos y procedimientos utilizados para devenir en autor/a -cómo se dice, cómo se reconoce, cómo se postula como tal- $\mathrm{y}$ al mismo tiempo atender a una serie de factores que intervienen tanto en la construcción de la imagen como en su legitimación. Sin olvidar, además, que las figuras autoriales están ante una reconfiguración permanente exigida, entre otras cosas, por su propia obra. Es decir, estamos en un panorama en el cual "el escritor debe constantemente legitimar su proceso creativo elaborando una imagen de autor a la medida de su obra" (Maingueneau 26).

A esto hay que agregar que, así como la imprenta introdujo nuevas prácticas autoriales performativas (como la paronimia y la pseudonimia), en la actualidad, con la globalización y la revolución mediática, los escritores y artistas, ya familiarizados con la cultura de masas, acuden a diferentes métodos de escenificación autorial -donde las redes sociales juegan un papel fundamental-, al mismo tiempo que están conscientes que la puesta en escena es cada vez más pública. En otras palabras, se hace necesario tener en cuenta que "en la cultura del espectáculo, en la era del márketing de la imagen, todo individuo que se encuentra arrojado al espacio público está obligado a construir y controlar la imagen que proyecta de sí mismo” (Meizoz, “Qué entendemos?” 188).

Dentro de este marco, pensar en la imagen de autor de artistas y escritoras mujeres contemporáneas implica, a su vez, considerar otros factores como la ligazón, o condena, que se le ha dado a las mujeres con su cuerpo y con la función reproductora, impidiéndoles acceder al estatuto de autora. $\mathrm{O}$, dicho de otra forma, la sistemática deslegitimación de las mujeres como creadoras culturales e intelectuales a lo largo de la historia. En vista de ello, cabe prestar atención a las estrategias de autorrepresentación y reconocimiento a las que acuden las autoras ya no solo dentro de sus respectivas sociedades patriarcales y heteronormativas, sino dentro del propio campo cultural, donde, lamentablemente, aún se reproducen en gran medida estos presupuestos.

de pelea, y la del segundo, una fotografía de Jaime Guerra, sacada aproximadamente a inicios de los 2000, en la que sale Rita Indiana en un primerísimo primer plano fumando. 
Atendiendo a estas ideas, y aplicando las metáforas pluralizantes a las que apela José-Luis Diaz, con las que se concibe al autor/a como un puzle, como un juego de mecano, como un caleidoscopio (Diaz, "Cuerpo" 31), abordar el caso de Rita Indiana desde las recientes teorías sobre la autoría resulta interesante y rico en lecturas y problematizaciones. Por una parte, su trayectoria como autora se enmarca en un momento en el que diferentes escritoras mujeres nacidas entre los setenta y noventa irrumpen en las letras latinoamericanas con un impacto local e internacional y con una circulación transnacional, ya sea en sellos de sus propios países o extranjeros. En un momento en el que las escritoras se han ido posicionando con fuerza en el campo cultural/literario latinoamericano. Pero en el que aún las letras caribeñas continúan en un estado periférico y de mayor invisibilización con respecto a otras zonas de la región. Ante lo cual, Rita Indiana se posiciona como una de las voces femeninas caribeñas de esa generación con mayor reconocimiento y celebridad literaria.

Asimismo, otra de las piezas singulares de la figura autorial de Rita Indiana es que en sus casi diez años de recorrido artístico -en los que ha desarrollado diversas propuestas estéticas- ha construido diferentes facetas autoriales, experimentando con más de un tipo de acto de enunciación y en más de una escenografía autorial. Esto nos lleva a prestar atención a los heterogéneos elementos que han interactuado en la configuración de su imagen, o imágenes, de autora, tales como el contenido, tono y estética de sus propias realizaciones discursivas, ficcionales y no ficcionales (que van desde sus creaciones artísticas a su palabra plasmada en entrevistas, post y columnas, donde su yo autorial cobra protagonismo); a los efectos que tienen en su reconocimiento las realizaciones discursivas metafóricas y propias de la industria editorial, donde su voluntad interactúa con labores de terceros (como el caso de su apodo y su nombre o el diseño de los libros); junto a las realizaciones discursivas que se han materializado ya sea en su propio cuerpo o en diferentes escenarios/espacios culturales (libros, textos en medios periodísticos digitales, redes sociales, álbumes musicales, videoclips, programas de TV, espectáculos/conciertos en vivo, etc.).

No obstante, todo ello hay que problematizarlo tomando en consideración los procesos que su figura ha experimentado dentro del propio campo cultural. Es decir, que ha transitado del casi anonimato de los circuitos alternativos-periféricos (como lo fue durante su trabajo en las bandas Casiful y Miti miti, y en sus tres primeras publicaciones) a espacios mediáticos, al convertirse en una celebridad artística (principalmente tras el éxito del álbum El juidero [2010]); y que en consecuencia de ello hubo un replanteamiento en la carrera de la autora, quien optó por volver a circuitos más exclusivamente literarios o de la composición musical fuera de escenarios, situación que fue de la mano del reconocimiento y consagración de su autoría en el panorama de las letras hispanoamericanas.

Sumado a esto, no podemos pasar por alto que en los vaivenes del devenir autora de Rita Indiana han participado también otros dispositivos vinculados a políticas de la

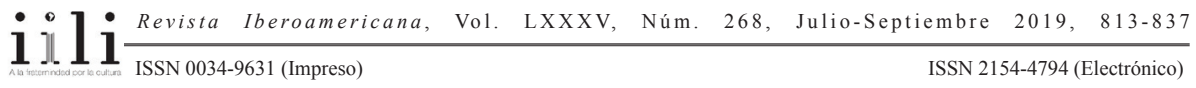


industria editorial, las políticas económicas y a la mercadotecnia, que han contribuido no solo en la circulación de su obra sino sobre todo en la internacionalización y visibilización de su imagen, como lo es la incorporación en el catálogo de la editorial Periférica y el haber sido durante dos años colaboradora en El País, donde su régimen mediático estuvo determinado en gran medida por el tono polémico y controvertido de algunos de sus escritos socioculturales y no precisamente por aquellos relativos a la crítica cultural-estética. Con ello, se hace oportuno preguntarnos ¿hasta qué punto, en esta nueva forma de existencia pública de la literatura y el arte, la visibilidad dada por el reconocimiento y prestigio literario otorgado por la valoración artística hecha por los pares y la institución cultural, se logra de forma independiente a la visibilidad dada por la fama y la celebridad artística? Es decir, ¿hasta qué punto el campo cultural posee una autonomía real en cuanto al campo del poder económico y político? (Golubov 35).

Como consecuencia de todos estos elementos y procesos, se debe atender y problematizar otra pieza clave en la construcción del retrato autorial de Rita Indiana, que ha favorecido, o permitido, que su postura de autora se reafirme en su distancia con la hegemonía, en su contradiscursividad, en su disidencia. Y es que si bien la autora asume su enunciación desde la marginalidad-que como sabemos es más por asuntos de género y de territorio (El Caribe) que de raza y de clase- hoy en día dentro del campo cultural e intelectual Rita Indiana ya no está en una situación de subalternidad. En este punto me parece apropiado acudir al cuestionamiento de Natalie Heinich sobre "¿Cómo mantener una posición marginal en una sociedad que ha acabado por hacer de esta marginalidad la condición de reconocimiento?" (en Pérez y Torras 37). Con ello, más allá de presentar una respuesta, me pregunto si en Rita Indiana esa toma de consciencia de sí misma como un sujeto que puede aparecer en el orden del discurso autorial le ha permitido velar por un quehacer artístico -o una imagen autorial- donde confluye la vocación por la creación artística con la vocación por un activismo sociocultural, o si esto es independiente de esta situación de privilegio.

Ya desde otro ángulo, y como parte de las identificaciones de todas estas heterogéneas piezas autoriales difíciles de jerarquizary del tejido que con estas se ha ido construyendo, los últimos acontecimientos en lo que compete a la figura autorial de Rita Indiana también dan pautas para futuras problematizaciones. Esto se debe a que la reactivación de su figura en 2017, sorprendentemente, no ha estado marcada por una intención de enfatizar en su creación literaria sino más bien en la musical, y continuar reafirmando su postura ideológica ante la contingencia. Esto se plasma, entre otras cosas, en su propio Twitter, como espacio de enunciación del yo y, por tanto, de autopromoción de la imagen y postura autorial, ya que a lo largo del año 2017 predominaron los post relativos al acontecer político de República Dominicana o la región de El Caribe, al movimiento de la No Impunidad y sobre todo a la difusión de su nuevo videoclip. Esta situación no deja de llamar la atención ya que no solo "salió del letargo" la Rita Indiana-cantante sino también la escritora, al publicar pocos días antes de su concierto,

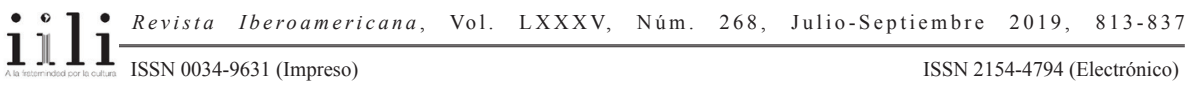


el 13 de marzo de 2017, su cuento "Los trajes 1975" en la revista mexicana Letras libres, el cual, no solo es su primera publicación desde el 2015, sino que también, y en vista de su título, podría ser - o no- la antesala de su próxima novela Los trajes. ${ }^{23}$ Si bien es normal que esto haya causado bastante menos "ruido" y atención mediática que su nuevo single, es curioso que la artista solo lo haya anunciado mediante un par de retwitteos del post de la revista, sin ningún enunciado personal, ni descriptivo ni apreciativo. Actitud similar a las escuetas palabras que publicó a los pocos días de ser galardonada con el premio de la Asociación de Escritores del Caribe. Ante lo cual también me pregunto si este silencio, o desinterés, no es acaso una estrategia para generar suspenso, considerando a su obra musical como un dispositivo que le inyecta visibilidad a su obra literaria.

Con esto, y dado a que la configuración de una imagen de autor es una compleja práctica de individualización en un contexto puntual, donde los autores deben buscar mecanismos de control sobre su propia imagen al mismo tiempo que mecanismos de sociabilización de esta, me pregunto de qué manera la postura de autora que ha decidido crear y defender puede o no llegar a constituirse como una prisión de su propia obra, condenándola a producir discursos que se enmarquen dentro de ese relato autorial. Es decir, hasta qué punto su obra futura puede verse afectada, o favorecida, por los propios lineamientos que le dicta dicho posicionamiento.

En vista de lo abordado, no puedo más que asumir la lectura que aquí propongo desde las interrogantes, las disyuntivas, condicionantes y conjeturas y no desde la afirmación, ni la aseveración, ya que quizás el único hecho concreto es que la figura autorial de Rita Indiana, como artefacto cultural, sigue en work in progress.

\section{BIBLIOGRAFÍA}

Bourdieu, Pierre. Las reglas del arte: génesis y estructura del campo literario. Barcelona: Anagrama, 1997.

Bustamante, Fernanda, ed. Rita Indiana. Archivos. Berlín: Ediciones Cielonaranja, 2017. Butler, Judith. Vida precaria. El poder del duelo y la violencia. Buenos Aires: Paidós, 2006.

Caparrós, Martín. "Por la crónica". Mejor que real. Crónicas ejemplares. Ed. Jorge Carrión. Barcelona: Anagrama, 2012. 607-612.

Carrión, Jorge. "Prólogo". Mejor que real. Crónicas ejemplares. Ed. Jorge Carrión. Barcelona: Anagrama, 2012. 13-43.

Chichizola, Antonella. "Rita Indiana: prueba de que los tiempos están cambiando y también la literatura”. Altavoz. 22 abr. 2016. <http://altavoz.pe/2016/04/22/15268/

$\overline{21}$ El cuento está disponible en <http://www.letraslibres.com/espana-mexico/revista/los-trajes-1975>. 
hombre-blanco-heterosexual-requisitos-para-ser-escritor-en-america-latina $>$. May. 2017.

Chillón, Albert. Literatura y periodismo. Una tradición de relaciones promiscuas. Zaragoza: Universitat Autònoma de Barcelona, Universitat Jaume I, Universitat de Valencia, 1999.

Derrida, Jacques. Firma, acontecimiento, contexto. 1971. Edición electrónica de la Escuela de Filosofía de la Universidad Arcis. $<$ http://ddooss.org/articulos/textos/ derrida_firma.pdf $>.10$ may. 2017.

Diaz, José-Luis. "Las escenografías autoriales románticas y su puesta en discurso". Los papeles del autor/a: marcos teóricos sobre la autoría literaria. Eds. Aina Pérez y Meri Torras. Madrid: Arco Libros, 2016. 155-185.

"Cuerpo del autor, cuerpo de la obra. Algunos aspectos de su relación en la época romántica". Tropelías. Revista de teoría de la literatura y literatura comparada 24 (2015): 31-50.

Discolai. “'Dios Salve a la Montra': 6 reversiones de Rita Indiana que debes escuchar". Revista Discolai. 24 mar. 2017. <https://discolai.com/2017/03/24/dios-salve-a-lamontra-6-reversiones-de-rita-indiana-que-debes-escuchar/>. May. 2017.

Foucault, Michel. “¿Qué es un Autor?”. Elseminario.com.ar. 2000-05 [1969]. $<$ http://23118.psi.uba.ar/academica/carrerasdegrado/musicoterapia/informacion_ adicional/311_escuelas_psicologicas/docs/Foucault_Que_autor.pdf $>$. May. 2017.

Tecnologías del yo. Y otros textos afines. Barcelona: Paidós, 1990.

Golubov, Nattie. "Del anonimato a la celebridad literaria: la figura autorial en la teoría feminista". Mundo Nuevo, n. 16, año VII (enero-junio 2015): 29-48.

Heinich, Nathalie. "Créateurs er penseurs". De la visibilité. Excellence et singularité en régime médiatique. París: Gallimard, 2012. 158-167.

Hutchinson, Sydney. "Una propuesta transgenérica de la música de Rita Indiana: el potencial transformador de sus canciones y videoclips, y el compromiso de leerescuchar entre líneas/pa'lla'o". Rita Indiana. Archivos. Ed. Fernanda Bustamante. Berlín: Ediciones Cielonaranja, 2017. 351-386. [Versión en inglés: "Listening Sideways: The Transgenre Work of Rita Indiana". Tigers of a Different Stripe: Performing Gender in Dominican Music. Chicago: University of Chicago Press, 2016. 173-210].

Jaime, Karen. “Da pa' lo' do': Rita Indiana's Queer, Racialized Dominicanness”. Small Axe, vol. 19, n. 2 (julio 2015): 85-93.

Maingueneau, Dominique, "Escritor e imagen de autor", Tropelías. Revista de teoría de la literatura y literarura comparada, 24 ([2013] 2015): 17-30.

Meizoz, Jérôme. "Escribir, es entrar en escena: la literatura en persona". Estudios, vol. 21/2013, n. 42 (2016): 253-269.

$111 \frac{\text { Revista Iberoamericana, Vol. LXXXV, Núm. 268, Julio-Septiembre 2019, }}{1113-837}$ 
“QQué entendemos por 'postura’?”. Los papeles del autor/a: marcos teóricos sobre la autoría literaria. Eds. Aina Pérez y Meri Torras. Madrid: Arco Libros, 2016. 187-204.

Morales, Ed. "Rita Indiana: no la llamen Lady Gagá". 80 grados. Prensa sin Prisa. 1 jul. 2011. <http://80grados.net/rita-indiana-no-la-llamen-lady-gaga/>. [También publicado en El sonido de la música en la narrativa dominicana: Ensayos sobre identidad, nación y performance. Ed. Médar Serata. Santo Domingo: Instituto de Estudios Caribeños, 2012. 317-326].

Peguero, Sorayda. "Rita Indiana vuelve a la música". El Espectador. 30 mar. 2017. $<$ http://elespectador.com/jscroll_view_entity/node/687047/full/p608333shown>. 30 mar. 2017.

Pérez, Aina y Torras, Meri, eds. Los papeles del autor/a: marcos teóricos sobre la autoría literaria. Madrid: Arco Libros, 2016.

Pérez, Aina; Torras, Meri y Cróquer, Eleonora. “A manera de presentación: ninguna voz es transparente. Autoría de mujeres para un corpus visibilizador". Mundo Nuevo 16 (enero-junio 2015): 15-27.

Rita Indiana. “Adiós al merengue”. Harper's Bazaar. Enero de 2013: 93.

"Rita Indiana escritora y cantante". Cambio16 diario digital. Santo Domingo, 17 dic. 2013. < cambio16.com.do/not/1704/rita_indiana_escritora_y_cantante/>. 1 may. 2014. [El sitio web actualmente no disponible. La entrevista se encuentra en Cambio 16, n. 2178 (2013): 52-54, ISSN 0211-285X].

"Entrevista a Rita Indiana durante el aniversario de la revista Contratiempo". Youtube. <https://youtube.com/watch?v=6oGXVjiltqo>. 1 may. 2017.

"Magia negra". El País. 9 oct. 2013. <http://internacional.elpais.com/ internacional/2013/10/09/actualidad/1381345925_372245.html>. 11 oct. 2013.

"Rita Indiana en ZONA R.L. TV". Youtube. 16 nov. 2014. <https://youtube. com/watch? $\mathrm{v}=\mathrm{jSDTkNgoPi}>$ > 1 dic. 2015.

"Tu afro no cabe en la foto". El País. 29 jul. 2014. <http://elpais.com/ elpais/2014/07/28/eps/1406564419_461753.html>. 9 ene. 2015.

“Disney gay". El País. 21 oct. 2014. <http://elpais.com/elpais/2014/10/20/ eps/1413806688_470532.html>. 3 nov. 2014.

"Matrioskas en la cancha". El País. 27 may. 2014. <http://elpais.com/ elpais/2014/05/22/eps/1400773784_580758.html>. 27 may. 2014.

“El problema haitiano". El País. 3 mar. 2015.<http://elpais.com/elpais/2015/03/02/ eps/1425310058_707982.html>. 3 mar. 2015.

“El éxodo apátrida". El País. 7 jul. 2015. <http://elpais.com/elpais/2015/07/03/ eps/1435923219_602706.html>. 5 feb. 2016.

"República Dominicana, el chivo expiatorio". El País. 17 ago. 2015. <http:// elpais.com/elpais/2015/08/17/eps/1439810805_950365.html>. 25 ago. 2015. 
"Los valores familiares de Cartoon Network". El País. 20 oct. 2015. <http:// elpais.com/elpais/2015/10/16/eps/1445011245_189895.html>. 5 feb. 2016.

"Vida gay 1: tomar tu mano". El País. 28 jul. 2015. <http://elpais.com/ elpais/2015/07/27/eps/1438014425_582160.html>. 28 ago. 2015.

"Rita Indiana: 'Mi literatura es una bomba de temas urgentes del Caribe"'. Agencia EFE. 21 abr. 2016. < http://efe.com/efe/america/cultura/rita-indiana-mi-literaturaes-una-bomba-de-temas-urgentes-del-caribe/20000009-2904136>. 30 abr. 2016. "Los trajes, 1975". Letras Libres. 13 mar. 2017.<http://letraslibres.com/espanamexico/revista/los-trajes-1975>. 20 mar. 2017.

“Columnas". El País. <http://elpais.com/autor/rita_indiana_hernandez/a>.

"Columnas". Prodavici. <http://prodavinci.com/?s=rita+indiana\&imageField. $\mathrm{x}=9$ \&imageField. $\mathrm{y}=12$ \&imageField $=$ Search $>$.

Twitter.@RitaIndiana

Rivera-Velázquez, Celiany. "A una década de la importancia de ser Rita Indiana Hernández: la incursión en videoarte, sonido y performance de La Montra del Caribe hispano". Rita Indiana. Archivos. Ed. Fernanda Bustamante. Berlín: Ediciones Cielonaranja, 2017. 293-328. [Versión original: "The Importance of Being Rita Indiana-Hernández: Woman Centered Video, Sound and Performance Interventions Within Spanish Caribbean Cultural Studies". Globalizing Cultural Studies: Ethnographic Interventions in Theory, Method \& Policy. Eds. Mc Carthy, C. et al. Nueva York: Peter Lang, 2007. 205-226].

Rotker, Susana. La invención de la crónica. México D.F.: Fondo de Cultura Económica, 2005.

Tola, Raúl. "El español en cinco libros”. El País. 21 abr. 2016. <http://cultura.elpais. com/cultura/2016/04/20/actualidad/1461154192_768335.html>. 5 may. 2017.

Torrado, Lorna. "Travesías bailables: revisión histórica en la música de Rita Indiana Hernández”. Revista Iberoamericana, vol. LXXIX, n. 243 (abril-junio 2013): 465-478.

Vera Rojas, María Teresa. “¡Se armó el juidero! Cartografías imprecisas, cuerpos disidentes, sexualidades transgresoras: hacia una lectura queer de Rita Indiana Hernández". Rita Indiana. Archivos. Ed. Fernanda Bustamante. Berlín: Cielonaranja, 2017. 259-289. [Una versión inicial de este artículo se publicó en Prosopopeya. Revista de Crítica Contemporánea, 7 (2011-2012): 185-205].

Villoro, Juan. “La crónica, ornitorrinco de la prosa”. Antología de crónica latinoamericana actual. Ed. Darío Jaramillo Agudelo. Barcelona: Alfaguara, 2012. 577-582.

Wittig, Monique. El pensamiento heterosexualy otros ensayos. Madrid: Egales, [1992] 2006.

ZONAR.L. TV. "Rita Indiana en ZONAR.L. TV”, Zona R.L. TV. 16 nov. 2014. <https:// www.youtube.com/watch?v=jSDTkNgoPi8>. May. 2017.

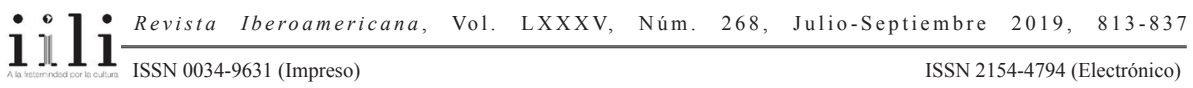


Palabras clave: figura autorial, imagen de autor, postura, marco sociopolítico

Recibido: diciembre 2017

Aprobado: diciembre 2018 